Toudji et al., Afr J Tradit Complement Altern Med., (2018) 15 (1): $42-58$

https://doi.org/10.21010/ajtcam.v15i1.5

\title{
ANTIBACTERIAL AND ANTI-INFLAMMATORY ACTIVITIES OF CRUDE EXTRACTS OF THREE TOGOLESE MEDICINAL PLANTS AGAINST ESBL KLEBSIELLA PNEUMONIAE STRAINS
}

\section{Gerard A. Toudji ${ }^{1}$, Emmanuel Thiombiano ${ }^{2}$, Simplice D. Karou ${ }^{1,3^{*}}$, Kokou Anani ${ }^{1}$, Yao Adjrah ${ }^{1}$, Holaly E Gbekley ${ }^{1}$, Martin Kiendrebeogo ${ }^{2}$, Yaovi Ameyapoh ${ }^{1}$, Jacques Simpore ${ }^{3}$}

${ }^{1}$ Ecole Supérieure des Techniques Biologiques et Alimentaires, (ESTBA-UL), Université de Lomé, Togo; ${ }^{2}$ Laboratoire de Biochimie et de Chimie appliquées (LABIOCA), UFR-SVT, Université Ouaga I Professeur Joseph KI-ZERBO, Burkina Faso; ${ }^{3}$ Centre de Recherche Biomoléculaire Pietro Annigoni (CERBA), Burkina Faso

*Corresponding Author Email: simplicekarou@ @otmail.com

\begin{tabular}{|c|}
\hline \multicolumn{1}{|c|}{ Article History } \\
Received: Apr. 18, 2017 \\
Revised Received: Aug. 26, 2017 \\
Accepted: Aug. 30, 2017 \\
Published Online: Dec. 29, 2017
\end{tabular}

\begin{abstract}
Background: Pithecellobium dulce (Roxb.) Benth., Securidaca longepedunculata Fresn and Cryptolepis sanguinolenta (Lindl.) Schlt are three plants widely used in the Togolese traditional medicine to treat microbial infections. Some studies reported their antibacterial activity alone but until know there no data concerning their possible interaction with conventional antibiotics. The main objective of this study was to investigate the antibacterial activity of the association of the crude extracts of the three plants with some conventional antibiotics. We further evaluate the antioxidant and the anti-inflammatory activities of the extracts on rat's model.

Materials and methods:The antimicrobial activity was evaluated by the broth microdilution assay and the Fractional inhibitory concentrations (FIC) determined by the checkerboard method. The anti-inflammatory activity was evaluated using the Carrageenan- induced rat paw edema model. The antioxidant activities and the phenol contents were determined by spectrophotometry.

Results: The MICs of hydroethanolic extract of plants ranged from 3.125 to $100 \mathrm{mg} / \mathrm{mL}$ on Klebsiella pneumoniae strains. Synergistic action was observed only with the combination of Imipenem/P. dulce, imipenem/C. sanguinolenta, amikacin/P. dulce and amikacin/C. sanguinolenta against the ESBL negative Klebsiella pneumoniae strain. Of the 21 associations, 15 were antagonistic on the ESBL-producing strains. The indifference effect was observed with the combination of the extract of Securidaca longepedunculata and the following antibiotics imipenem, amikacin, tetracyclin, ciprofloxacin, Cefotaxim; and Sulfametoxazol+Trimethoprim. The in vitro anti-inflammatory with Lipoxygenase inhibition activity was best with $C$. sanguinolenta extract while the in vivo paw edema model revealed that $S$. longepedunculata was the highest reducer of paw edema. In addition white blood cells count and biochemical parameters such as total proteins and immunoglobulins were significantly affected by the administration of plant extracts.

Conclusion: This study revealed that the three plants although they may inhibit the bacterial growth by themselves, but there is also a possible synergistic action with the commercial antibiotics. Further investigations are needed to identify the active compounds and their mechanism of action.
\end{abstract}

Keywords: antibiotics, extended-spectrum beta lactamase, plant extract, bacteria, Togo

\section{Introduction}

The discovery of antibiotics marked the advent of a new era in the modern medicine and many lives were saved. Unfortunately, the inadequate use of these drugs has been accompanied by the rapid emergence of resistant strains (Davies and Davies, 2010). The development of resistance in microbes has become a major public health problem requiring considerable effort to find a solution (Barbosa and Levy, 2000; N'Guessan et al., 2007; Demain and Sanchez, 2009). 
Beta-lactams remain the most common agents prescribed for the treatment of bacterial infections so they are the main object of resistance among Gram-negative bacteria worldwide (Shaikh et al., 2015). However, because of their lower cost, oral use, lesser side effects and availability in the market, their use continues unabated (Adwan et al., 2010).Clinically, the continuous emergence of extended-spectrum beta-lactamase producing bacteria (ESBL) has considerably reduced the effectiveness of the antibiotic arsenal and, therefore, increased the rate of therapeutic failures (Bradley and Arrieta, 2001). Some previous studies pointed out Escherichia coli and Klebsiella pneumoniae as the leading Enterobacteriaceae producing beta-lactamase and then responsible for chronic infections (Delgado-Valverde $e t$ al., 2013).

Pathogen invasion involves reactive local changes. The neighboring cells release antimicrobial agents to defend the host, leading to acute or chronic inflammation (Serhan et al., 2005). Acute inflammation is a short-term process that is characterized by the classic signs of swelling, redness, pain, heat and loss of function - due to tissue infiltration by plasma and leukocytes (Kumar et al., 2004). Polymorphonuclear leukocytes (PMNL) are essential innate immune cells that determine the resistance of the host to various bacterial and fungal infections. In the persistent state as infections caused by ESBLs, chronic inflammatory pathological conditions are established, and there is a continuous inflow of PMNLs (Porth et al., 2011). Activated PMNL may alter serum proteins by producing cytolytic enzymes, oxygen free radicals and inflammatory mediators that cause extensive collateral damage to host tissues (Chen et al., 2009; Rani et al., 2013). Chronic inflammation leading to the production of reactive oxygen species and reactive nitrogen species may mediate diseases such as cancer, diabetes, cardiovascular, neurological and pulmonary disease (Reuter et al., 2010, Brooker 2011).

During inflammatory reactions, pro-and anti-inflammatory mediators are produced. Some literature reports demonstrate a key regulatory role for lipoxygenases and their metabolites in many physiological processes, placing them at the center of many disease models (Wisastra and Dekker, 2014). Lipoxygenases are a group of oxidative enzymes with non-heme iron atom in their active site, involved in the regulation of inflammatory responses by generation of pro-inflammatory mediators known as leukotrienes or anti-inflammatory mediators known aslipoxins. These enzymes catalyze the insertion of oxygen in polyunsaturated fatty acids such as linoleic acid, linolenic acid and arachidonic acid to give hydroperoxides (Meriles et al., 2000; Azila and Don, 2012; Chedea and Jisaka, 2013). Lipoxygenases are widely distributed in plants, fungi and animal tissues (Alfadda and Sallam, 2012; Kye and Huh, 2015).

Herbal medicines are being used increasingly and plants have become the focus of intense study in terms of alternatives for antimicrobial resistance and inflammatory pathological challenges (Adwan et al., 2010). In Togo, traditional healers often use plant species such as Pithecellobium dulce (Roxb.) Benth., Securidaca longepedunculata Fresn and Cryptolepis sanguinolenta (Lindl.) Schlt for the treatment of inflammatory diseases, wounds, ears, malaria and many other health problems. The main objective of this study was to investigate the antibacterial activity of the association of the crude extracts of the three plants with some conventional antibiotics. We further evaluate the antioxidant and the anti-inflammatory activities of the extracts on rat's model.

\section{Materials and Methods \\ Plants materials and extraction}

The stem bark of Pithecellobium dulce (Roxb.) Benth. (Mimosaceae) was collected around the University of Lomé. The roots of Securidaca longepedunculata Fres. (Polygalaceae) and Cryptolepis sanguinolenta (Lindl.) Schlt(Periplocaceae/Asclepiadaceae) were purchased in the herbal market "Atikpodzi" of Lomé in November 2015.The plant materials were botanically authenticated at the department of plant science and ecology of the University of Lomé (Togo) where specimens were deposited (numbers: 7521FDS/UL, 9491 FDS/UL andTG201546 respectively). Plants samples were dried in laboratory at room temperature reduced into powder and submitted to percolation with ethanolwater $(70: 30, \mathrm{~V} / \mathrm{V})$ for $72 \mathrm{~h}$. The extract was filtered through Whatman paper filter and evaporated to dryness under vacuum with an evaporator type Heidorph.

\section{Animals}

Wistar rats of both sexes weighing between 200 and 250g were provided by“Laboratoire de Microbiologie de Contrôle de Qualité des Denrées Alimentaires", University of Lomé. The animals were feed with standard pellets. They were kept under alternative cycle of 12 hours of light and darkness(Baker et al., 1979). The Institutional Animal Ethical Committee approved the protocol of the study.

\section{Chemicals and media}

Folin Ciocalteu-reagent, $\mathrm{NaH}_{2} \mathrm{PO}_{4}, \mathrm{Na}_{2} \mathrm{HPO}_{4}$, sodium carbonate, aluminum trichloride $\left(\mathrm{AlCl}_{3}\right)$, gallic acid and quercetin were purchased from Sigma-Aldrich Chemie (Steinheim, Germany)., 2,2-Dipheny-1-picrylhydrazyl (DPPH), trichloroacetic acid, methanol, ethyl acetate and n-butanol were supplied by Fluka Chemie (Buchs, Switzerland). Potassium hexacyanoferrate $\left[\mathrm{K}_{3} \mathrm{Fe}(\mathrm{CN})_{6}\right]$ was from Prolabo (Paris, France); ascorbic acid and iron trichloride $\left(\mathrm{FeCl}_{3}\right)$ were supplied by Labosi (Paris, France). All solvents and drugs used in this study were of analytical grade. All culture media were from BioRad or Bio Mérieux (France). Commercial antibiotics were from Bio Rad. 


\section{Microbial strains and culture media}

The study microorganisms included fifty ESBL Klebsiella pneumoniae strains and one strain of non ESBL Klebsiella pneumoniae isolated from pathologic specimens notably urine pus and blood at the Polyclinelle WossinuGbogbo of Lomé, following the methods in force in the center. Briefly, urine and pus samples were directly seeded on the Eosin methylene Bleu agar (Biorad, France). The blood samples were used to inoculate vials of blood culture hemoline (Bio Mérieux, France) for at least seven days to detect the bacterial growth. Afterwards, the Gram staining was performed on the subcultures prior to the identification with the API 20E System (Bio Mérieux, France).

\section{Susceptibility testing and detection of beta lactamases production on agar diffusion}

The susceptibility to antibiotics was performed by agar disk diffusion and the results interpreted following the recommendations of the Antimicrobial susceptibility Committee of the French Society for Microbiology (SFM, 2015). The categorization criteria are defined as sensitive (S), intermediate (I) and resistant (R) for each antibiotic used. However, all intermediate strains were considered as resistant in this study. A total of 19 antibiotics : Amoxicillin+clavulanate (AMC), Cefalotin (CF), Cefotaxim (CTX), ceftazidim (CAZ) trimethoprim-sulfamethoxazole (SXT), gentamicin (GM), nalidixic acid (NA), Tobramicin (TM), Norfloxacin (NOR), ciprofloxacin (CIP), Netilmycin (NET), Imipenem (IPM), cefoxitin (FOX), amikacin (FOX), Chloramphenicol (C), Kanamycin (K), Doxycyclin (DO), levofloxacin (LEV), Colistin (CL) were tested.

The production of ESBL was assayed by the double disk synergy technique described by Jarlier et al. (1988). The Amoxicillin+clavulanic acid disk (AMC) was deposited between third generation cephalosporins (C3G)disks namely ceftazidime, cefotaxime or ceftriaxone at a distance of 2 to $3 \mathrm{~cm}$ on Muller Hinton agar plate. After 18 to 24 hours incubation, the production of ESBL was revealed by the appearance of a characteristically inhibition zone between the AMC disk and those of C3G referred to as a "champagne-cork".

\section{Determination of MICs and MBCs}

The minimum inhibitory concentration (MICs) and the minimum bactericidal concentration (MBCs)were determined using the 96 wells plate broth microdilution method recommended by National Committee for Clinical and Laboratory Standards Institute (NCCLS, 2002). Overnight colonies from bacterial strains were suspended in $0.9 \%$ $\mathrm{NaCl}$ to $0.5 \mathrm{Mac}$ Farland standards $\left(10^{8} \mathrm{cfu} / \mathrm{mL}\right)$. Theses suspensions were diluted with Müller Hinton broth to a final bacterial load of $10^{5} \mathrm{cfu} / \mathrm{mL}$ in the wells, containing ranges of concentrations of antibiotics or plant extracts. Imipenem (IMP), amikacin (AN), chloramphenicol (C), tetracycline (TE), ciprofloxacin (CIP) and trimethoprim-sulfamethoxazole (SXT) were the tested antibiotics. After incubation of plates at $37^{\circ} \mathrm{C}$ during 24 hours, MICs were determined as the lowest concentration that inhibited visible bacterial growth in wells. Subculture was made from wells with no visible growth on nutrient agar and incubated under the same conditions to determine the MBC. This was defined as the lowest concentration that yielded no growth after subculturing. The ratio MBC/MIC was used to qualify the activity as bacteriostatic for $\mathrm{MBC}>\mathrm{MIC}$ and bactericide for equal values of $\mathrm{MIC}$ and $\mathrm{MBC}$.

\section{Fractional inhibitory concentration (FIC)}

Effects of combination of plants extracts with antibiotics were assessed by the checkerboard test according to Fankam et al. 2011on ESBL Klebsiella pneumoniae and non ESBL strains. The antibacterial combination concerned the MICs of each extract and "Imipenem (IPM), Chloramphenicol (C), Amikacin (AN), Tetracyclin (TE), Cefotaxim (CTX), Sulfamethoxazole-Trimethoprim (SXT), Ciprofloxacin (CIP). Fractional inhibitory concentration (FIC) was then calculated by adding the FIC values of extracts and antibiotic $\left(\mathrm{FIC}_{\mathrm{E}}+\mathrm{FIC}_{\mathrm{A}}\right)$. $\mathrm{FIC}_{\mathrm{E}}$ and $\mathrm{FIC}$ values correspond to lowest concentrations of extracts and antibiotic presenting no growth.

\section{Antioxidant activities}

\section{DPPH radical scavenging activity}

The antioxidant activity of the extracts was assessed through their ability of scavenging stable radicals 2, 2diphenyl-1-picrylhydrazyl (DPPH). This activity was determined using the stable radical DPPH, according to the method described by Velazquez et al. (2003). The assay was performed in triplicate using 96 micro-well plates (Nalge Nunc International, NY, USA). Aliquots of serials dilutions were made from extracts solution $(10 \mathrm{mg} / \mathrm{mL})$ in methanol by mixing $100 \mu \mathrm{L}$ of each specimen with $200 \mu \mathrm{L}$ of $\mathrm{DPPH}(20 \mathrm{mg} / \mathrm{L}$ in methanol). After 15 min of incubation in darkness at ambient temperature, the resultant absorbance was recorded at $517 \mathrm{~nm}$ with a spectrophotometer $(\mathrm{EPOCH}$ 251465, Biotek instruments USA Micro well plate Reader) against a blank well with $100 \mu \mathrm{L}$ methanol and $200 \mu \mathrm{L}$ of DPPH. The concentrations scavenging $50 \%$ of free radicals $\left(\mathrm{IC}_{50}\right)$ were determined by radicals scavenging activity percentage curves plotted from each extract by GraphPad Prism 6. Quercetin and Gallic acid were used as reference products. The percentage of absorbance inhibition was calculated according to the equation: 
$\%$ Inhibition $=\frac{\text { Acontrol }- \text { Asample }}{\text { Acontrol }} \times 100$

\section{FRAP: Fire Reducing Assay Power}

The reducing power of extracts was determined according to method as described by Compaore et al. (2011). A reaction mixture consisting of $0.5 \mathrm{~mL}$ of extract, $1.25 \mathrm{~mL}$ of phosphate buffer $(0.2 \mathrm{~mol} / \mathrm{L}, \mathrm{pH} 6.6)$ and $1.25 \mathrm{~mL}$ of aqueous potassium hexacyanoferrate $(1 \%)$ was incubated for $30 \mathrm{~min}$ before the addition of TCA and centrifugation at $3000 \mathrm{rpm}$ for 10 minutes. In 96 micro-wells, the upper layer solution $(125 \mu \mathrm{L})$ was mixed with $125 \mu \mathrm{L}$ of $\mathrm{H}_{2} \mathrm{O}$ and $25 \mu \mathrm{L}$ of $\mathrm{FeCl}_{3}$ fresh solution. Ascorbic acid was used to produce the calibration curve by reading the absorbencies at $700 \mathrm{~nm}\left(Y=105.90 X-8.71 ; r^{2}>0.99 ; P<0.0001\right)$. The iron (III) reducing activity of each sample was obtained from 2 independent triplet determinations and expressed in mgAAE/g of extract.

\section{Deoxyribose degradation inhibitory assay}

The extracts power to scavenge the hydroxyl radical was evaluated using the deoxyribose inhibition degradation test as described by Perjesi et al. (2011). The hydroxyl radical is produced in situ by iron sulfate which decomposes the hydrogen peroxide to hydroxyl radical attacking the deoxyribose (component of DNA) at 2' and causes the opening of the cycle with production of malonylaldéhyde. This product forms with the thiobarbituric acid a pink complex.

A mixture was prepared with the sample $(100 \mu \mathrm{L}, 1 \mathrm{mg} / \mathrm{mL})$ in phosphate buffer $(50 \mathrm{nM}, \mathrm{pH} 7.4)$, EDTA $(100 \mu \mathrm{L}, 1.04 \mathrm{mM})$, ferrous sulfate $(100 \mu \mathrm{L}, 100 \mathrm{mM})$; deoxyribose $(100 \mu \mathrm{L}, 60 \mathrm{mM})$ and hydrogen peroxide $(100 \mu \mathrm{L}$, $10 \mathrm{mM})$. The volume was completed to $1 \mathrm{~mL}$ with phosphate buffer. The mixture was incubated at $37^{\circ} \mathrm{C}$ for 1 hour and $1 \mathrm{~mL}$ of trichloroacetic acid (15\%), $1 \mathrm{~mL}$ of thiobarbituric acid $(0.675 \%$ in $25 \mathrm{mMNaOH})$ were added and heat at $100^{\circ} \mathrm{C}$ for $15 \mathrm{~min}$. After cooling in an ice bath for 5 minutes, the tubes were centrifuged at $3000 \mathrm{rpm}$ for $10 \mathrm{~min}$, then the supernatant $(200 \mu \mathrm{L})$ was introduced into 96 micro-well plates to measure the absorbance. This was accessed at 532 nm against a blank containing neither hydrogen peroxide nor iron sulfate. Quercetin was used as reference. The experiment was performed in triplicate and deoxyribose degradation inhibition was expressed as a percentage compared to the control without extract.

\section{Lipid peroxidation inhibitory assay}

The extracts ability to inhibit lipid peroxidation using lecithin was evaluated according to the method described by Compaore et al. (2011). The reaction mixture contained $100 \mu \mathrm{L}$ of sample $(1 \mathrm{mg} / \mathrm{mL})$ in phosphate buffer (10mM, pH 7.4), $100 \mu \mathrm{L}$ of ferrous sulphate $(100 \mathrm{mM}), 100 \mu \mathrm{L}$ of EDTA $(1,04 \mathrm{mM}), 100 \mu \mathrm{L}$ of hydrogen peroxide $10 \mathrm{mM}$ and $100 \mu \mathrm{L}$ of an opalescent suspension of lecithin $(10 \mathrm{mg} / \mathrm{mL})$ in phosphate buffer and the volume was made up to $1 \mathrm{~mL}$ with phosphate buffer. The resulting solution was incubated for an hour at $37^{\circ} \mathrm{C}$ before adding $1 \mathrm{~mL}$ of acid ( $15 \%$ trichloroacetic acid and $0.675 \%$ thiobarbituric acid). The tubes were then heated to $100^{\circ} \mathrm{C}$ for $15 \mathrm{~min}$ and cooled in an ice bath for 5 minutes. After centrifugation at 3000rpm for $10 \mathrm{~min}$, the absorbance was measured at $532 \mathrm{~nm}$ against a blank neither iron sulphate nor hydrogen peroxide. Quercetin was used as reference substance.

\section{Inhibition of 15-lipoxygenase (15-LOX) enzyme}

The principle is based on the reaction between oxygen and the unsaturated fatty acids of 1-4 diene structure. Linoleic acid serves as a substrate (Adebayor et al., 2015). The 15-LOX (Sigma) was made up to a working solution of 200 units $/ \mathrm{mL}$ and kept on ice. Test sample or control $(3.75 \mu \mathrm{L}$ in DMSO) was added to $142.5 \mu \mathrm{L}$ of $15-\mathrm{LOX}$ in a 96 micro-well plate. After 5 min incubation at room temperature, $150 \mu \mathrm{L}$ substrate solutions $(10 \mu \mathrm{L}$ linoleic acid dissolved in $30 \mu \mathrm{L}$ ethanol, made up to $120 \mathrm{~mL}$ with $2 \mathrm{M}$ borate buffer at $\mathrm{pH}$ 9) were added to the solution. The absorbance was immediately measured at $234 \mathrm{~nm}$. Zileuton was used as a positive control, while DMSO was used as the negative control (100\% enzyme activity or no enzyme inhibition). Enzyme inhibition percentage of extract compared with negative control (100\% enzyme activity) was calculated as follows:

$$
\% \text { Inhibition }=\frac{\text { Asample }- \text { Ablank }}{\text { Anegative control }- \text { Ablank }} \times 100
$$

The results were expressed as $\mathrm{IC}_{50}$, i.e. concentration of the extracts and controls that resulted in $50 \% 15$-LOX inhibition plotted on a graph by GraphPad Prism 6

\section{In vivo Anti- inflammatory activity by Carrageenan- induced rat paw edema model}

The method of Winter et al. (1962) was used to evaluate the anti-inflammatory activity with some minor modifications. Rats were randomly allocated into four groups of five. Group I served as control and received distilled 
water. Group II of animals received indomethacin $(10 \mathrm{mg} / \mathrm{kg})$. Group III and IV were given hydroethanolic extract of $S$. longepedunculata, $C$. sanguinolenta and $P$. dulce respectively at doses of 400 and $800 \mathrm{mg} / \mathrm{kg}$, p.o. After $30 \mathrm{~min}, 0.1 \mathrm{~mL}$ of $1 \% \mathrm{~W} / \mathrm{V}$ carrageenan freshly prepared in normal saline was injected into the sub plantar of left hind paw of rat. The paw volumes were then measured by the dislocation of water column in a plethsmometer at 0, 1, 2, 3, 4 and 5 hours after carrageenan injection (Olajide et al., 2000; Dosseh et al., 2014). The percentage of anti-inflammatory activity was calculated by using the formula below:

$\%=\left(1-\frac{\text { Vtest }}{\text { Vcontrol }}\right) x 100$

Where: Vcontrol is the mean volume of the control group; Vtest the mean volume of the test group

\section{Blood analysis and total protein electrophoresis}

Group II to V were collected at the late phase of inflammation. Blood was collected by retro-orbital puncture in dry and EDTA tubes and was treated according to the statutorily accepted procedures in the medical laboratory bioassays. White cells, red cells and platelets counted were performed using hematology analter KX $21 \mathrm{~N}$. Total proteins were assayed by spectrophotometry using spectrometer Erba Chem 6. Total serum proteins electrophoresis of rats was carried out using the Minicap instrument and the Minicap Protein (E) 6 kit which enables the separation of serum proteins into five major fractions: Albumin, Alpha-1 globulin, Alpha-2 globulin, Beta globulin and Gamma globulin.

\section{Phytochemical investigations \\ Total phenolic contents determination}

The total phenols content was evaluated using Folin-Ciocalteu colorimetric assay described by Compaoré et al. (2011) with minor modifications. Mixture consisting of $25 \mu \mathrm{L}$ of extracts, $125 \mathrm{~mL}$ of Folin-Ciocalteu reagent $(0.2$ $\mathrm{mol} / \mathrm{L})$ was incubated for $5 \mathrm{~min}$ before adding $100 \mathrm{~mL}$ of sodium carbonate $(75 \mathrm{~g} / \mathrm{L})$. After one hour incubation in dark, absorbance was recorded at $760 \mathrm{~nm}$ with microplate reader. Gallic acid was used as standard $\left(y=221.7 x ; R^{2}=0.9996\right)$. The results were expressed in milligrams of Gallic Acid Equivalent for 100mg dry extract (mgEAG/100mg).

\section{Total Flavonoids Contents determination}

Total Flavonoids Content was determined according to previous method described by Compaoré et al. (2011). One hundred microliters of sample and $100 \mu \mathrm{L}$ of $\mathrm{AlCl}_{3}(2 \%)$ were mixed in 96 micro-well plate and incubated for 10 min. The absorbance was measured at $415 \mathrm{~nm}$ with microplate reader. The standard curve was generated with variable concentration of quercetin at $415 \mathrm{~nm}\left(y=0.01686 X+0.05917 r^{2}=0.9986 p<0.0001\right)$ and the results were expressed as $\mathrm{mgQE} / \mathrm{g}$ of sample.

\section{The proanthocyanidin content determination}

The method of acid / butanol described by Chamorro et al., (2012) was used with a slight modification to evaluate the proanthocyanidin. Two grams of $\mathrm{NH}_{4}(\mathrm{Fe}) \mathrm{SO}_{4}$ were dissolved with $200 \mathrm{ml}$ 190/10 (v/v) of 1-butanol / HCl mixture. In a test tube, $7 \mathrm{ml}$ of the prepared solution and $200 \mu \mathrm{l}$ of the extract at $1 \mathrm{mg} / \mathrm{ml}$ (dissolved in ethanol and water) were mixed. The test tubes were heated at $95^{\circ} \mathrm{C}$ for 90 minutes. After the reaction time, tubes were cooled in an ice bath and the absorbance of various solutions was assessed at $565 \mathrm{~nm}$. The presence of proanthocyanidins was revealed by the red color in reaction tubes. The blank of the reaction is carried out under the same conditions without extract. The condensed tannins (CT) were expressed in micrograms of equivalents of Gallic Acid per milligram of dry matter $(\mu \mathrm{gEGA} / \mathrm{mg})$. The standard curve was generated with variable concentration of this compound comprised between 0 and $200 \mathrm{mg} / \mathrm{L} \mathrm{Y}=97,27 \mathrm{X}+4,153$

$\mathrm{r}^{2}=0,9949 ; p<0,0001$. Assays were carried out in triplicate and the results expressed as mean.

\section{Statistical Analysis}

The results were represented as a mean \pm SEM of the indicated number of experiments. One-way analysis of variance (ANOVA) followed by Dennett's test or by ANOVA by Bonferroni's test were used to find the statistical differences between control and tested groups. All statistical analyses were performed using GraphPad Prisms Version 6.1 and SYSTAT11. 


\section{Results \\ Antibiotic susceptibility}

A total of 50 ESBL producing Klebsiella pneumoniae strains were tested for their susceptibility to commercial antibiotics. Figure 1 indicates the resistance rates for each antibiotic. Antibiotics such as AMC, CF, CTX, CAZ, SXT were totally inactive against all the tested strains, while IMP and CL showed 100\% of inhibition. For the rest of antibiotics, the percentages of resistant strains were above 60\%, except FOX and AN for which the rates were did not reach $10 \%$.

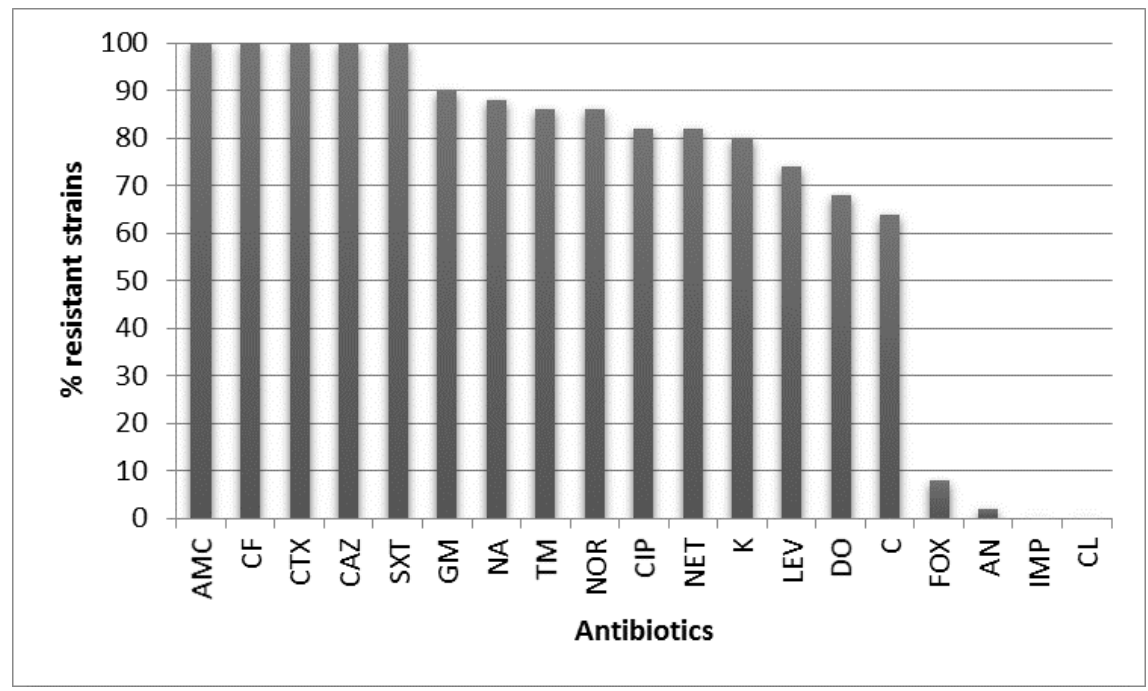

Figure 1: Antibiotic resistance pattern of the study strains

\section{Antibacterial activity of the plants extracts alone}

In total, 25 bacterial strains of $K$. pneumoniae isolated from the pathologic samples were tested with three extracts. Only one ESBL negative bacterial strain was used in the study, the bacterium was isolated from pus. The test with this strain yielded the following MBC/MIC values for the three extracts respectively: S. longepedunculata: 25/25 (Bactericidal effect); P. dulce: 25/12.5 (Bacteriostatic effect) and C sanguinolenta: 12.5/3.12 (bacteriostatic effect). The remaining strains were ESBL producing bacteria. Table 1 displays the antibacterial activity of the extracts in relation with the source of isolation of these pathogens. According to the table, the MICs ranged between $6.25 \mathrm{and} 100 \mathrm{mg} / \mathrm{mL}$ while the MBCs ranged between 25 and $100 \mathrm{mg} / \mathrm{mL}$ for the susceptible strains. For other strains the MICs were above $100 \mathrm{mg} / \mathrm{mL}$. The extract of $S$. longepedunculata exerted bactericidal effect on 7 strains that recorded equal values of MBC and MIC of $25 \mathrm{mg} / \mathrm{mL}$. Of these strains, 4 were isolated from urine, 1 from pus and 2 from blood. For $P$. dulce, the bactericidal effect was observed at a concentration of $50 \mathrm{mg} / \mathrm{mL}$ on five strains, 2 isolated from urine, 1 from pus and 2 from blood. Finally, bactericidal effect was observed on one strain isolated from urine with $50 \mathrm{mg} / \mathrm{mL}$ of $C$. sanguinolenta extract. For the rest, the extract was bacteriostatic.

Table 1: Distribution of bacterial strains in relation with the extracts MIB/MIC values and the source of isolation

\begin{tabular}{lcccl}
\hline \multirow{2}{*}{ MIC/MBC } & \multicolumn{3}{c}{ Number of bacterial strains } & \multirow{2}{*}{ Remark } \\
& \multicolumn{3}{c}{ Urines/ Pus/ Blood } & \\
\cline { 2 - 4 } & S. longepedunculata & P. dulce & C. sanguinolenta & \\
\hline $6.25 / 25$ & $1 / 1 / 0$ & $0 / 0 / 0$ & $1 / 0 / 0$ & Bacteriostatic \\
$12.5 / 25$ & $0 / 1 / 1$ & $0 / 1 / 0$ & $1 / 1 / 0$ & Bacteriostatic \\
$25 / 25$ & $4 / 1 / 2$ & $0 / 0 / 0$ & $0 / 0 / 0$ & Bactericidal \\
$25 / 50$ & $0 / 0 / 0$ & $0 / 1 / 1$ & $1 / 0 / 0$ & Bacteriostatic \\
$25 / 100$ & $1 / 0 / 0$ & $0 / 0 / 0$ & $0 / 0 / 0$ & Bacteriostatic \\
$50 / 50$ & $0 / 0 / 0$ & $2 / 1 / 2$ & $1 / 0 / 0$ & Bactericidal \\
$50 / 100$ & $0 / 1 / 0$ & $1 / 0 / 1$ & $0 / 2 / 0$ & Bacteriostatic \\
$25 / \mathrm{ND}$ & $0 / 0 / 0$ & $0 / 0 / 0$ & $0 / 0 / 0$ & Bacteriostatic \\
$50 / \mathrm{ND}$ & $1 / 0 / 1$ & $2 / 1 / 1$ & $0 / 0 / 0$ & Bacteriostatic \\
$100 / \mathrm{ND}$ & $0 / 0 / 0$ & $1 / 0 / 0$ & $1 / 0 / 0$ & Bacteriostatic \\
ND & $5 / 1 / 3$ & $5 / 2 / 2$ & $7 / 2 / 7$ & Bacteriostatic \\
\hline
\end{tabular}

Data in the table represent the number of strains isolated from a corresponding pathological product namely urine, pus ans blood. MBC: minimum bactericidal concentration expressed in $\mathrm{mg} / \mathrm{mL}$, MIC: minimum inhibitory concentration expressed in $\mathrm{mg} / \mathrm{mL}$. ND for MBC and MIC values above $100 \mathrm{mg} / \mathrm{mL}$. 


\section{Antibacterial activity of the conventional antibiotics alone}

The antibiotics were tested on the ESBL negative strain and on the ESBL positive strain that presented the highest values of MBC/MIC values with the plant extract. The results of these tests are presented in the table 2. According to the table the lowest values of MIC/MBC were recorded with the ESBL negative strain rather than the ESBL positive one. IPM, AN, TC and S. longepedunculata were bactericidal while C, CIP, SXT, CTX, PD and CS were bacteriostatic against the ESBL negative strain. The ESBL producing strain resisted highly to C, TE, CIP, CTX, SXT but IPM, AN, PD, SL were bactericidal.

Table 2: Antibiotic MIC/MBC values

\begin{tabular}{lclcc}
\hline Antibiotics & \multicolumn{4}{c}{ MIC/MBC } \\
\cline { 2 - 5 } & ESBL- & Remarks & ESBL+ & Remarks \\
\hline IPM & $0.25 / 0.25$ & Bactericidal & $1 / 1$ & Bactericidal \\
AN & $3 / 3$ & Bactericidal & $6 / 6$ & Bactericidal \\
C & $6 />12$ & Bacteriostatic & $>12 />12$ & ND \\
TE & $3 / 3$ & Bactericidal & $>24 />24$ & ND \\
CIP & $0.5 / 1$ & Bacteriostatic & $>8 />8$ & ND \\
CTX & $0.75 / 1.5$ & Bacteriostatic & $>24 />24$ & ND \\
SXT & $2.5 / 5$ & Bacteriostatic & $>20 />20$ & ND \\
PD* & $12.5 / 25$ & Bacteriostatic & $50 / 50$ & Bactericidal \\
SL* & $25 / 25$ & Bactericidal & $25 / 25$ & Bactericidal \\
CS* & $3.125 / 12.5$ & Bacteriostatic & $50 / 100$ & Bacteriostatic \\
\hline
\end{tabular}

MIC/MBC for antibiotics were expressed in $\mu \mathrm{g} / \mathrm{mL}$. * MIC/MBC for extracts were expressed in $\mathrm{mg} / \mathrm{mL}$

IPM: Imipenem; AN: Amikacin; C: Chloramphenicol; CIP: Ciprofloxacin; TE: Tetracyclin; CTX: Cefotaxim; SXT:

Sulfametoxazol+Trimethoprim. PD: Pithecellobium dulce. SL: Securidaca longepedunculata. CS: Cryptolepis sanguinolenta. ND: not determined

\section{Antibacterial activity of the associations}

The results of the combination of the plant extracts with antibiotics IPM, AN, C, TE, CIP, CTX, SXT and their isolated activity on ESBL producing Klebsiella pneumoniae strain and those of ESBL negative Klebsiella Pneumoniae are shown in Table 3. They were expressed as fractions of inhibitory concentrations for each antibiotic and for each extract.

Synergistic action was observed only with the combination of IPM/PD, IPM/CS, AN/PD and AN/CS against the ESBL negative Klebsiella pneumoniae strain. The trend was different for the ESBL producing strain. Antagonism was observed on the two strains with the combination of all extracts and chloramphenicol as well as C. Sanguinolenta extract combined with cefotaxim and tetracyclin. Particularly on the BLSE positive strain of Klebsiella pneumoniae, the antagonistic effect was observed at several levels in addition to those already reported. Overall, there was more antagonism effect generated by this strain than that of the ESBL negative because of the 21 associations of extracts, 15 were antagonists on the ESBL-producing strains. The indifference effect was observed with the combination of the extract of Securidaca longepedunculata and the following antibiotics IPM, AN, TE, CIP, CTX, SXT. 
Table 3: Antibacterial activity and FIC indices Klebsiella pneumoniae $\mathrm{MIC}$ value recorded $\left.\mathrm{MIC}_{\mathrm{A}} / \mathrm{MIC}_{\mathrm{E}}\left(\sum \mathrm{FICI}\right) \mathrm{FIC}_{\mathrm{A}}+\mathrm{FIC}_{\mathrm{E}}\right)$

\begin{tabular}{ccccccc}
\hline Combinations & \multicolumn{3}{c}{ ESBL- } & \multicolumn{3}{c}{ ESBL+ } \\
\cline { 2 - 6 } IPM/PD & $\mathrm{MIC}_{\mathrm{A}} / \mathrm{MIC}_{\mathrm{E}}$ & $\mathrm{FIC}_{\mathrm{A}}+\mathrm{FIC} \mathrm{E}\left(\sum \mathrm{FICI}\right)$ & Remarks & $\mathrm{MIC}_{\mathrm{A}} / \mathrm{MIC}_{\mathrm{E}}$ & FIC $_{\mathrm{A}}+\mathrm{FIC}_{\mathrm{E}}\left(\sum \mathrm{FICI}\right)$ & Remarks \\
\cline { 2 - 7 } IPM/SL & $0.25 / 12.5$ & $0.125+0.25(0.375)$ & Synergistic & $1 / 50$ & $2+0.5(2.5)$ & Antagonism \\
IPM/CS & $0.25 / 3.125$ & $0.125+0.125(0.25)$ & Synergistic & $1 / 100$ & $1+1(2)$ & Indifference \\
AN/PD & $3 / 12.5$ & $0.5+0.25(0.75)$ & Synergistic & $6 / 50$ & $1+4(5)$ & Antagonism \\
AN/SL & $3 / 25$ & $1+0.5(1.5)$ & Indifference & $6 / 25$ & $1+1(2)$ & Indifference \\
AN/CS & $3 / 3.125$ & $0.25+0.125(0.375)$ & Synergistic & $6 / 100$ & $1+1(2)$ & Indifference \\
C/PD & $6 / 12.5$ & $>4$ & Antagonism & $>12 / 50$ & $0.5+4(4.5)$ & Antagonism \\
C/SL & $6 / 25$ & $>5$ & Antagonism & $>12 / 25$ & $>5$ & Antagonism \\
C/CS & $6 />3.125$ & $>5$ & Antagonism & $>12 / 100$ & $>5$ & Antagonism \\
TE/PD & $3 / 12.5$ & $0.5+1(1.5)$ & Indifference & $>24 / 50$ & $>5$ & Antagonism \\
TE/SL & $3 / 25$ & $1+1(2)$ & Indifference & $>24 / 25$ & $>1(2)$ & Indifference \\
TE/CS & $3 / 3.125$ & $>5$ & Antagonism & $>24 / 3.125$ & $>4$ & Antagonism \\
CIP/PD & $0.5 / 12.5$ & $1+0.5(1.5)$ & Indifference & $>8 / 50$ & $1+1(2)$ & Antagonism \\
CIP/SL & $0.5 / 25$ & $1+1(2)$ & Indifference & $>8 / 25$ & $2+1(3)$ & Indifference \\
CIP/CS & $0.5 / 3.125$ & $1+1(2)$ & Indifference & $>8 / 100$ & $4+2(6)$ & Antagonism \\
CTX/PD & $0.75 / 12.5$ & $1+0.5(1.5)$ & Indifference & $>24 / 50$ & $>5$ & Antagonism \\
CTX/SL & $0.75 / 25$ & $1+1(2)$ & Indifference & $>24 / 25$ & $>5$ & Antagonism \\
CTX/CS & $0.75 / 3.125$ & $2+1(3)$ & Antagonism & $>24 / 100$ & $>5$ & Antagonism \\
SXT/PD & $2.5 / 12.5$ & $1+0.5(1.5)$ & Indifference & $>20 / 50$ & $1+0.5(1.5)$ & Antagonism \\
SXT/SL & $2.5 / 25$ & $1+1(2)$ & Indifference & $>20 / 25$ & $1+2(3)$ & Indifference \\
SXT/CS & $2.5 / 3.125$ & $1+1(2)$ & Indifference & $>20 / 100$ & Antagonism \\
\hline
\end{tabular}

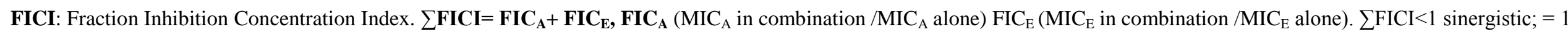

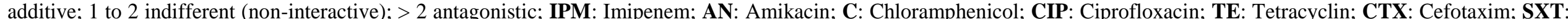

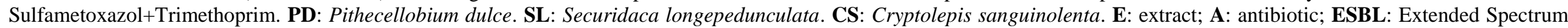
Beta-Lactamase; + positive; - : negative. 


\section{Total phenolic, flavonoid and proanthocyanidin contents}

Table 4 presents the phenol contents of the extracts. The total phenolic contents were $88.93 \pm 2.44,18.06 \pm 0.8$ and $13.85 \pm 0.78 \mathrm{mgGAE} / 100 \mathrm{mg}$ for $P$. dulce, $S$. longepedunculata and $C$. sanguinolenta, respectively. The total flavonoid contents were very low in the extracts, moreover, flavonoids was not detected in the extract of $C$. sanguinolenta. The extract of $P$. dulce exhibited the highest concentrations in proanthocyanidins $(67.44 \pm 0.80$ $\mu \mathrm{gEAA} / \mathrm{mg})$. The remaining extracts yielded amounts below $15 \mu \mathrm{gEAA} / \mathrm{mg}$.

Table4: Phenol contents of the extracts

\begin{tabular}{lccc}
\hline Extracts & TPC $(\mathrm{mgGAE} / 100 \mathrm{mg})$ & TFC $(\mu \mathrm{gEQ} / \mathrm{mg})$ & TPAC $(\mu \mathrm{gEAA} / \mathrm{mg})$ \\
\hline P. dulce & $88.93 \pm 2.44$ & $0.74 \pm 0.03$ & $67.44 \pm 0.80$ \\
S. longepedunculata & $13.85 \pm 0.78$ & $0.34 \pm 0.01$ & $9.21 \pm 0.39$ \\
C. sanguinolenta & $18.06 \pm 0.8$ & $\mathrm{ND}$ & $11.22 \pm 0.17$ \\
\hline
\end{tabular}

$\mu \mathrm{gEAA} / \mathrm{g}: \mu \mathrm{g}$ ascorbic acid equivalents/gram; mg GAE/100mg: mg gallic acid equivalent/100gram; $\mu \mathrm{gQE} / \mathrm{mg}: \mu \mathrm{g}$ quercetin equivalent/milligram. TPC: Total phenolic content; TFC: Total flavonoid content; TPAC : Total proanthocyianidin content. ND: Non detected

\section{Antioxidant activity}

The antioxidant activity of the plant extracts was evaluated by several methods and the results are shown in Table 5. According to DPPH assay, the $\mathrm{IC}_{50}$ concentration was lower for $P$. dulce $(11.3 \mu \mathrm{g} / \mathrm{mL})$ than the two other plants $(\mathrm{p}<0.001)$. Reference products as gallic acid and quercétine yielded 1.23 and $8.54 \mu / \mathrm{mL} \mathrm{IC}_{50}$ values respectively. The same trend was observed for the ferric reduction assay. Thus, the best power was found with $P$. dulce extract, $1.34 \pm 0.03 \mathrm{mmolAAE} / \mathrm{g}$, while gallic acid, a reference compound showed $8.74 \mathrm{mmol} \mathrm{AAE} / \mathrm{g}$. Lypoxigenase $\mathrm{IC}_{50}$ were similar for $P$. dulce and $S$. Longepedunculata. The highest value was for $C$. sanginolenta, about $0.47 \mu \mathrm{g} / \mathrm{mL}$. Statistically, the difference between the reference compound zileuton activity with the plants extracts was significant. The deoxyribose degradation and lipid peroxidation inhibition activities expressed in percentage by the three plant extracts and quercetin at $100 \mu \mathrm{g} / \mathrm{mL}$ are also presented in table 5. The two inhibition percentage activities for the three plants ranged from 52.92 to 77.39 while quercetin as reference product exhibited very high inhibition (90.40\%)

Table5: Antioxidant activities

\begin{tabular}{lccccc}
\hline Specimen & $\begin{array}{c}\mathrm{DPPH} \% \mathrm{IC}_{50} \\
(\mu \mathrm{g} / \mathrm{mL})\end{array}$ & $\begin{array}{c}\text { FRAP } \\
(\mathrm{mmolAAE} / \mathrm{g})\end{array}$ & $\begin{array}{c}\mathrm{LOX} \% \mathrm{IC}_{50} \\
(\mu \mathrm{g} / \mathrm{mL})\end{array}$ & $\mathrm{I} \% \mathrm{DRB}$ & $\mathrm{I} \% \mathrm{LPO}$ \\
\hline P. dulce & $11.33 \pm 1.26$ & $1.34 \pm 0.03$ & $0.79 \pm 0.04$ & $66.33 \pm 3.31$ & $70.95 \pm 1.69$ \\
S. longepedunculata & $985.33 \pm 50.36$ & $0.06 \pm 0.01$ & $0.78 \pm 0.06$ & $76.54 \pm 2.58$ & $60.88 \pm 2.46$ \\
C. sanguinolenta & $554.67 \pm 79.43$ & $0.18 \pm 0.00$ & $0.47 \pm 0.03$ & $77.39 \pm 2.62$ & $50.92 \pm 1.91$ \\
Quercetin & $8.54 \pm 0.40$ & $5.46 \pm 0.17$ & $\mathrm{ND}$ & 90.40 & 90.02 \\
Gallicacid & $1.23 \pm 0.39$ & $8.74 \pm 0.11$ & $\mathrm{ND}$ & $\mathrm{ND}$ & $\mathrm{ND}$ \\
Ascobicacid & $\mathrm{ND}$ & $4.20 \pm 0.13$ & $\mathrm{ND}$ & $\mathrm{ND}$ & $\mathrm{ND}$ \\
Zileuton & $\mathrm{ND}$ & $\mathrm{ND}$ & 0.083 & $\mathrm{ND}$ & $\mathrm{ND}$ \\
\hline
\end{tabular}

DPPH: 2.2-diphenyl-1- picrylhydrazyl ; FRAP: Ferric reducing antioxidant power; LOX: Lipoxigenase, I\% LPO: Lipid peroxidation inhibition percentage; I\% DRB: Deoxyribose degradation inhibition percentage.

\section{Anti-inflammatory activities}

The table 6 shows the inhibitory effect of the plant extracts and reference drug indomethacin on carrageenaninduced acute paw edema in rats compared to a control group. The difference in each group was statistically significant $(\mathrm{p}<0.05)$ except de the second hour of treatment with carrageenan where de P value was equal to 0.061 . The Maximum phlogistic response of carrageenan was observed at 3-5 h after the injection in the control animals. The inhibition in paw volumes of treated ( $S$. longepedunculata, $400 \mathrm{mg} / \mathrm{kg}$,p.o.) animals at $1 \mathrm{st}$, 4th and 5th hours after induction of paw edema was significant $(52.76,59.24$ and 72.25) as inindometacin treated animals $(27.56,63.04$ and 67.02)at the similar time points. The inhibition in paw volume of treated (S. longepedunculata, $800 \mathrm{mg} / \mathrm{kg}$, p.o.) animals at $1^{\text {st }} 3^{\text {rd }} 4^{\text {th }}$ and $5^{\text {th }}$ hour after injection of paw edema were significantly $(62.20,71.76,82.61$ and 96.86) highest followed by $C$. sanguinolenta treated animals at the same dose. The acute anti-inflammatory effect of $S$. longepedunculata, $C$. sanguinolenta, and $P$. dulce from the $3^{\text {rd }}$ to $5^{\text {th }}$ hour in rats was dose dependent. $P$. dulce treated animals of both dose showed the lowest $\%$ inhibition of paw edema. 
Table 6: Effect of plant extracts on the inhibition of left hind paw edema on carrageenan-induced inflammation in rats.

\begin{tabular}{|c|c|c|c|c|c|c|}
\hline \multirow[t]{2}{*}{ Treatment } & \multirow[t]{2}{*}{$\mathrm{mg} / \mathrm{kg}$} & \multicolumn{5}{|c|}{ Edema volume $(\mathrm{mL})(\%)$} \\
\hline & & $1 \mathrm{H}^{*}$ & $2 \mathrm{H}$ & $3 \mathrm{H}^{* *}$ & $4 \mathrm{H}^{* * *}$ & $5 \mathrm{H} * * *$ \\
\hline Distilled water & & $0.32 \pm 0.07 * *$ & $0.33 \pm 0.08$ & $0.43 \pm 0.05$ & $0.46 \pm 0.05$ & $0.48 \pm 0.04$ \\
\hline Indometacin & 10 & $\begin{array}{l}0.23 \pm 0.10 * * \\
(27.56)\end{array}$ & $\begin{array}{l}0.18 \pm 0.07 \\
(44.70)\end{array}$ & $\begin{array}{l}0.17 \pm 0.07 * \\
(60.00)\end{array}$ & $\begin{array}{l}0.17 \pm 0.07 * * \\
(63.04)\end{array}$ & $\begin{array}{l}0.16 \pm 0.06 * * \\
(67.02)\end{array}$ \\
\hline \multirow[t]{2}{*}{ P. dulce } & 400 & $\begin{array}{l}0.28 \pm 0.10 * \\
(11.81)\end{array}$ & $\begin{array}{l}0.24 \pm 0.10 \\
(28.79)\end{array}$ & $\begin{array}{l}0.34 \pm 0.06^{*} \\
(21.18)\end{array}$ & $\begin{array}{l}0.30 \pm 0.07 * * \\
(34.78)\end{array}$ & $\begin{array}{l}0.30 \pm 0.07 * * \\
(37.70)\end{array}$ \\
\hline & 800 & $\begin{array}{l}0.26 \pm 0.04 \\
(18.11)\end{array}$ & $\begin{array}{l}0.30 \pm 0.01 * \\
(9.85)\end{array}$ & $\begin{array}{l}0.28 \pm 0.03 * * \\
(35.29)\end{array}$ & $\begin{array}{l}0.25 \pm 0.03 * * * \\
(46.74)\end{array}$ & $\begin{array}{l}0.20 \pm 0.02 * * * \\
(58.12)\end{array}$ \\
\hline \multirow[t]{2}{*}{ S. longepedunculata } & 400 & $\begin{array}{l}0.15 \pm 0.06 * * \\
(52.76)\end{array}$ & $\begin{array}{l}0.17 \pm 0.09 * \\
(47.73)\end{array}$ & $\begin{array}{l}0.21 \pm 0.11 * * \\
(50.59)\end{array}$ & $\begin{array}{l}0.19 \pm 0.09 * * * \\
(59.24)\end{array}$ & $\begin{array}{l}0.13 \pm 0.01 * * * \\
(72.25)\end{array}$ \\
\hline & 800 & $\begin{array}{l}0.12 \pm 0.03 * * \\
(62.20)\end{array}$ & $\begin{array}{l}0.18 \pm 0.10 * \\
(44.70)\end{array}$ & $\begin{array}{l}0.12 \pm 0.04 * * * \\
(71.76)\end{array}$ & $\begin{array}{l}0.08 \pm 0.05 * * * \\
(82.61)\end{array}$ & $\begin{array}{l}0.01 \pm 0.00 * * * \\
(96.86)\end{array}$ \\
\hline \multirow[t]{2}{*}{ C. sanguinolenta } & 400 & $\begin{array}{l}0.17 \pm 0.05 * \\
(48.03)\end{array}$ & $\begin{array}{l}0.29 \pm 0.07 * \\
(11.36)\end{array}$ & $\begin{array}{l}0.30 \pm 0.06^{*} \\
(30.59)\end{array}$ & $\begin{array}{l}0.28 \pm 0.07 * \\
(39.67)\end{array}$ & $\begin{array}{l}0.27 \pm 0.07 \\
(44.50)\end{array}$ \\
\hline & 800 & $\begin{array}{l}0.13 \pm 0.07 * \\
(59.06)\end{array}$ & $\begin{array}{l}0.18 \pm 0.09 \\
(45.45)\end{array}$ & $\begin{array}{l}0.20 \pm 0.11^{*} \\
(53.53)\end{array}$ & $\begin{array}{l}0.18 \pm 0.10^{* *} \\
(61.96)\end{array}$ & $\begin{array}{l}0.16 \pm 0.09 * * \\
(67.54)\end{array}$ \\
\hline
\end{tabular}

Values are expressed as mean \pm S.E.M. $(n=4)$ were analyzed by one-way ANOVA followed by post hoc Dunnett's test, $* p<0.05$, ** $\mathrm{P}<0.01$, *** $\mathrm{P}<0.001$ when compared $\mathrm{PD}$, SL, CS groups with control and each value in parenthesis indicates the percentage inhibition.

The effects of plant extracts on hematological parameters affected by carrageenan treatment were further investigated. The results are presented in table 7. Globally, there was an increase of the white blood cells count ( $p$ $<0.05$ ) if compared to animal group without carrageenan treatment, however a slight decrease in the cell count was observed in the following treated groups: C. sanguinolenta $800 \mathrm{mg} / \mathrm{kg}$, S. longepedunculata $400 \mathrm{mg} / \mathrm{kg} \mathrm{and} 800 \mathrm{mg} / \mathrm{kg}$. No change was observed for red blood cells, hemoglobin and hematocrit amounts. The Platelets level generally decreased in all carrageenan treated group except in $P$. dulce treated animal group if compared to carrageenan free animal group.

Table 7: Alterations in hematological parameters

\begin{tabular}{lcccccc}
\hline \multicolumn{1}{c}{ Treatment } & Dose & \multicolumn{5}{c}{ Hematological and parameters } \\
\cline { 2 - 6 } & $\mathrm{mg} / \mathrm{kg}$ & $\begin{array}{c}\mathrm{WBC} \times 10^{3} \\
\left(\mathrm{cells} / \mathrm{mm}^{3}\right)\end{array}$ & $\begin{array}{c}\mathrm{RBC} \times 10^{6} \\
\left(\mathrm{cells} / \mathrm{mm}^{3}\right)\end{array}$ & $\mathrm{Hb}(\mathrm{g} / \mathrm{dL})$ & $\mathrm{HT}(\%)$ & $\begin{array}{c}\mathrm{PT} \times 10^{4} \\
\left(\mathrm{cells} / \mathrm{mm}^{3}\right)\end{array}$ \\
\hline Carrageanan free & & $8.72 \pm 1.22$ & $8.51 \pm 0.51$ & $15.02 \pm 0.64$ & $54.28 \pm 2.54$ & $80.72 \pm 6.33^{*}$ \\
Saline & 10 & $13.58 \pm 1.11$ & $8.57 \pm 0.33$ & $15.28 \pm 0.23$ & $53.84 \pm 1.69$ & $65.8 \pm 5.73^{*}$ \\
Indometacin & 400 & $14.24 \pm 1.80$ & $8.32 \pm 0.17$ & $14.08 \pm 0.75$ & $50.58 \pm 0.77$ & $63.48 \pm 58.76$ \\
$P$. dulce & 800 & $16.90 \pm 1.68$ & $8.09 \pm 0.23$ & $14.54 \pm 0.21$ & $50.56 \pm 0.65$ & $80.52 \pm 5.53^{*}$ \\
& 400 & $13.80 \pm 1.05$ & $8.65 \pm 0.29$ & $15.35 \pm 0.44$ & $53.05 \pm 1.20$ & $62.6 \pm 5.39$ \\
C. sanguinolenta & 800 & $11.60 \pm 1.49$ & $8.84 \pm 0.36$ & $15.60 \pm 0.37$ & $55.13 \pm 1.36$ & $59.58 \pm 9.20^{*}$ \\
& 400 & $11.08 \pm 1.08$ & $8.91 \pm 0.27$ & $15.85 \pm 0.34$ & $54.85 \pm 0.85$ & $56.43 \pm 4.91$ \\
S. longepedunculata & 800 & $11.53 \pm 2.23$ & $8.64 \pm 0.68$ & $16.47 \pm 1.85$ & $53.40 \pm 5.06$ & $22.03 \pm 6.66^{*}$ \\
\hline
\end{tabular}

Data represented as mean \pm S.E.M. $(n=4)$ analyzed by one way ANOVA followed by Dunnett's post hoc test. WBC: white Blood Cell, RBC: Red Blood Cell, Hb: Hemoglobin, HT: Hematocrit,PT: Platelets.

Table 8 displays the electrophoretic profiles of the total serum proteins of wistar rats groups undergoing treatments six hours after the induction of inflammation. The total protein level significantly increased for the indomethacin-treated group $(77.37 \pm 2.80 \mathrm{~g} / \mathrm{L})$ compared to the control group $(69.37 \pm 2.42 \mathrm{~g} / \mathrm{L})$. The same was noted for the albumin level of the negative control group $(25.72 \pm 1.47 \mathrm{~g} / \mathrm{L})$ with those of the IND, SL4 and SL8 groups respectively equal to $31.31 \pm 1.69 \mathrm{~g} / \mathrm{L}, 31.71 \pm 1.47 \mathrm{~g} / \mathrm{L} 31.68 \pm 1.47 \mathrm{~g} / \mathrm{L}$. A statistically significant difference was also found between the groups treated with extracts CS8 and SL4. Alpha1 globulins were 13.03 $\pm 0.97 \mathrm{~g} / \mathrm{L}$ and $16.11 \pm 0.97$ $\mathrm{g} / \mathrm{L}$ respectively for groups receiving CS8 and PD4 extracts ( $\mathrm{p}<0.05)$. There was a difference in the albumin ratio on Globulins $(\mathrm{A} / \mathrm{G})$ obtained in the SL4 groups $(0.81 \pm 0.07)$ and the negative control group $0.59 \pm 0.07$. The alpha2 and beta and gamma globulin parameters were not significantly influenced by either the extracts or the reference drug. 
Table 8: Assessment of plants extracts effect in correcting proteins involved in inflammation

\begin{tabular}{|c|c|c|c|c|c|c|c|c|}
\hline $\begin{array}{l}\text { Electrophoretic profile } \\
\text { of serum proteins }(\mathrm{g} / \mathrm{L})\end{array}$ & DW & IND & CS4 & CS8 & PD4 & PD8 & SL4 & SL8 \\
\hline Total protein & $69.37 \pm 2.42$ & $77.37 \pm 2.80 *$ & $72.82 \pm 2.42$ & $71.67 \pm 2.42$ & $69.80 \pm 2.42$ & $70.81 \pm 2.42$ & $71.47 \pm 2.42$ & $75.32 \pm 2.42$ \\
\hline Albumin & $25.72 \pm 1.47$ & $31.31 \pm 1.69 *$ & $28.65 \pm 1.47$ & $27.38 \pm 1.47$ & $27.44 \pm 1.47$ & $28.79 \pm 1.47$ & $31.71 \pm 1.47 *$ & $31.68 \pm 1.47^{*}$ \\
\hline$\alpha 1$ globulin & $13.94 \pm 0.97$ & $14.29 \pm 1.12$ & $14.91 \pm 0.97$ & $13.03 \pm 0.97$ & $16.11 \pm 0.97$ & $15.56 \pm 0.97$ & $13.81 \pm 0.97$ & $13.71 \pm 0.97$ \\
\hline$\alpha 2$ globulin & $5.14 \pm 0.38$ & $5.69 \pm 0.44$ & $4.84 \pm 0.38$ & $4.76 \pm 0.38$ & $5.70 \pm 0.38$ & $5.17 \pm 0.38$ & $4.74 \pm 0.38$ & $5.45 \pm 0.38$ \\
\hline$\beta$ globulin & $23.40 \pm 2.92$ & $25.30 \pm 3.38$ & $23.18 \pm 2.92$ & $25.66 \pm 2.92$ & $20.12 \pm 2.92$ & $20.79 \pm 2.92$ & $20.39 \pm 2.92$ & $23.88 \pm 2.92$ \\
\hline y globulin & $1.16 \pm 0.42$ & $0.86 \pm 0.50$ & $1.23 \pm 0.42$ & $0.84 \pm 0.42$ & $0.50 \pm 0.42$ & $0.53 \pm 0.42$ & $0.67 \pm 0.42$ & $0.60 \pm 0.42$ \\
\hline A/G Ratio & $0.59 \pm 0.07$ & $0.69 \pm 0.08$ & $0.65 \pm 0.07$ & $0.64 \pm 0.07$ & $0.65 \pm 0.07$ & $0.69 \pm 0.07$ & $0.81 \pm 0.07^{*}$ & $0.75 \pm 0.07$ \\
\hline
\end{tabular}

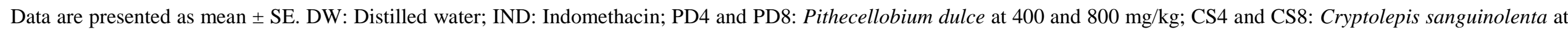
400 and $800 \mathrm{mg} / \mathrm{kg}$; SL4 and SL8: Securidaca longepedunculata at 400 and $800 \mathrm{mg} / \mathrm{kg}$. $* P<0.05$ significant difference when compared with negative control. 


\section{Discussion and Conclusions}

Enterobacteria such as Klebsiella pneumoniae producing extended spectrum beta-lactamases are known to exert high resistance against third generation cephalosporins and monobactams, therefore the choice of effective and safe antibiotic treatment is becoming restricted. Hence, alternative agents or extracts obtained from natural medicinal plants need to be introduced or combined with antibiotics for therapeutic use (Stermitz et al., 2000; Ishaq et al., 2015). In the the fight against ESBL bacterial according to their high resistance to classic antibiotics, the chronic inflammation situations they caused and disorders in the metabolism in which they are sometimes involved must be took into account. In Togo, as in the other low income African countries, people have an old tradition of plants use for health care (WHO, 2014). Continuously, scientists from Togo, focus their interest in improving traditional medicine. In this study, we investigated the resistance profiles of ESBL producing Klebsiella pneumoniae strains to conventional antibiotics and determine the antibacterial activity of three plant extracts on the same strains.

Klebsiella pneumoniae is naturally susceptible to a large number of classic antibiotics except Ampicilline Penicillin G, oxacillin, piperacillin ticarcilline and all macrolides. Classically according to CA-SFM and EUCAST, these antibiotics are not chosen to perform antibiogram unless there is a need to achieve Klebsiella specie's identification. Our results showed that only Imipenem and colistin inhibited all ESBL producing Klebsiella pneumoniae strains of the study. ESBLs are usually plasmid mediated. Since these plasmids are easily transmitted among different members of the Enterobacteriaceae, accumulation of resistance genes results in strains that contain multiresistant plasmids. For this reason, ESBL-producing isolates are resistant to a wide variety of antibiotics (Woldu, 2016). Moreover, the emergence of these multiply resistant Klebsiella strains is unfortunately accompanied by a relatively high stability of the plasmids encoding ESBLs (Podschun et al., 1998). Several explanations are possible to clarify resistance to inhibitors. Illiaquer (2010) revealed the presence of genes encoding for porines OmpK35 and Omp K36 on the membrane of Klebsiella pneumoniae multidrug resistance species that can change conformation weakening free movement of molecules trough these porines. Currently, the available data suggest a further increase in the incidence of ESBL-producing Klebsiella. As a result, the therapeutic options are becoming limited, so that in the near future there will be an urgent need for hospital infection control measures that counter the spread of ESBL-producing bacteria. Imipenem is very expensive antibiotic and colistin is not usually used due to its high toxicity. The alternative solution is first to test plants extract and after, to combine them to synthetic antibiotics in order to identify possible synergistic effects.

According to recorded MIC and MBC values, Cryptolepis sanguinolenta hydroethanolic extract was the most active extract on the ESBL negative strain of Klebsiella pneumoniae. This extract also showed interesting results on the ESBL producing strains. Several studies from the West African subregion have reported the potency of $C$. sanguinolenta against clinical malaria (Boye et al., 1990, Bugyei et al., 2010). According to Mills-Robertson et al., (2012) the chloroform fraction exhibited bactericidal activity against Klebsiella pneumoniae with bacteriostatic effect. In our study, the inhibition rate was $8 / 24(33 \%)$.

The extract of Pithecellobium dulce exhibited antibacterial activity (15/24) about $62.5 \%$ against ESBL producing Klebsiella pneumoniae strains with $66.7 \%$ of bacteriostatic effect. Pradeepa et al., (2014) studied the pulp extract of the plant and showed significant zone of inhibition in a dose dependent manner. The MIC and MBC values of the pulp extract against both Gram positive and Gram negative bacterial strains varied from $1 \mathrm{mg}$ to $5 \mathrm{mg}$. The results of the study indicated that $P$. dulce extract showed effective inhibitory activity against Gram negative bacteria.

Securidaca longepedunculata extract demonstrated the same rate of antibacterial activity against ESBL producing Klebsiella pneumoniae strains about $62.5 \%$ with $47.67 \%$ bactericidal effect. Karou et al., (2012) showed that the hydroethanolic root extract of this plant exhibited MIC about $900 \mu \mathrm{g} / \mathrm{ml}$ on Klebsiella pneumoniae CIP 52144 ESBL negative. According to Ndamitso et al. (2013), E. coli strains were susceptible to roots aqueous extracts. The plant leaves extracts were more active against several Gram negative strains.

From the three extracts, $S$. longepedunculata demonstrated the highest antibacterial activity and in terms of percentage of action, $C$. sanguinolenta had the lowest inhibition. The diversity observed in susceptibility of ESBL Klebsiella pneumoniae to extracts could be first explained by presence of capsule surrounding the bacteria as natural protection, porines almost damaged in its membrane which expression could extremely be modified enzymes harboring.

Consequently, the alternative could be the investigation for possible synergistic antibacterial combinations capable of improving empirical prescriptions. Thus, in vitro combination of plant extracts with different antibiotics was investigated against ESBL producing Klebsiella pneumoniae strains. As a result, several studies (Betoni et al., 2006) showed that there are varied interactions between plant extracts and antibiotics. In agreement with these studies, our study demonstrated synergism, additivity/indifference and antagonism between antibiotics and plants extracts. There were synergistic effects against ESBL negative Klebsiella pneumoniae strain, but not on ESBL producing Klebsiella pneumoniae strain. Ishaq et al. (2015) through their work have demonstrated that Klebsiella pneumoniae strain free of ESBL was inhibited with synergistic effect between cefotaxim, meropenem, ofloxacin, ceftriaxone and methanolic extract of Adiantum capillus-veneris. Olajuyigbe, et al. (2012) studied interactions between methanolic extract of Acacia mearnsii and eight antibiotics. The synergistic interaction was most expressed by combining the extract with erythromycin, tetracycline, nalidixic acid and chloramphenicol against K. pneumoniae (ATCC 10031). Plants antimicrobials have been found to be synergistic enhancers in that though they may not have any antimicrobial properties alone, but when they are taken concurrently with standard drugs they enhance the effect of that drug (Kamatou et al., 2006). 
Chronic inflammation situation caused by infection in living systems (Spooner and Yilmaz, 2011), is the greatest origin of free radicals generated and they can cause extensive damage to tissues and bio-molecules leading to complication of disease conditions, especially degenerative diseases, and extensive lysis (Halliwell et al., 1998).Main examples of these are poststreptococcal glomerulonephritis, acute rheumatic fever, or Bouillaud's disease, that is a delayed inflammatory complication of upper respiratory tract infections by Group A $\beta$-hemolytic Streptococcus (McDonald et al., 2004) and Cerebritis caused by Klebsiella pneumoniae in immune competent adults without predisposing factors such as neurosurgery or penetrating brain injury (Majumdar et al., 2009)

Many synthetic drugs are used to protect against oxidative damage but they have adverse side effects. Products are not accepted as immunological by living organisms in the same way. Some develop allergies and explained by hypersensitivity to it. With a patient developing an allergy to a product, the prescriber simply changes another product of the same pharmacological class. For these reasons among many others, it is necessary to seek and manufacture many molecules to frame the immune system. Another important alternative solution to the problem is to consume natural antioxidants from, nutraceuticals and traditional medicines (Yazdanparast et al., 2008).

In both DPPH and FRAP test, $P$. dulce bark extract expressed good scavenging of free radical and ferric reduction capacity and largely exceeded the two other plant extracts. The reference product as Gallic acid reduced more radicals than quercetin. $S$. longepedunculata and $C$. sanguinolenta extract were poor in reduction of free radicals.

According to lipid peroxidation and deoxyribose inhibition test, all plant extracts showed suitable results at almost the same rate with no significant statistically difference. The matter concentration did not linearly influence the inhibition percentage because the two results obtained from quercetin must be linked by Factor.

Therefore, it is clear that all the three extracts have good antioxidant activities in relation with the polyphenol contents. Hydroxyl radicals are the major active oxygen species causing lipid peroxidation and enormous biological damage (Katekhaye et al., 2012). They were produced in this study by incubating ferric-EDTA with ascorbic acid and $\mathrm{H}_{2} \mathrm{O}_{2}$ at $\mathrm{pH}$ 7.4, and reacted with 2-deoxy-2-ribose to generate a malondialdehyde (MDA)-like product. This compound forms a pink chromogen upon heating with TBA at low $\mathrm{pH}$ (Katekhaye et al., 2012). When $P$. dulce, S. longepedunculata and $C$. sanguinolenta extracts were added to the reaction mixture, they removed the hydroxyl radicals from the sugar and prevented the reaction. According to Katekhaye et al. (2012), the total antioxidant activity ( $\mathrm{IC}_{50}$ values) in DPPH assay by methanol and acetone $P$. dulce extract showed interesting results. Barku et al., (2012) confirmed that cryptolepine and quindoline compounds were present in the roots and in the stem of Cryptolepis sanguinolenta. From Akinmoladun et al. (2010) study, the reductive potential was $(0.26 \pm 0.00)$ in S. longepedunculata.

Carrageenan-induced rat paw oedema is a suitable experimental animal model to evaluate the anti-oedematous effect of natural products and is believed to be biphasic (Vinegar et al., 1969). The initial first phase occurs within an hour of carrageenan paw edema mediated by histamine and serotonin (Kumar and Jain, 2014), while the mediators in the later phase are suspected to be arachidonate metabolites (prostaglandins, leukotrienes) producing an oedema depending on mobilization of neutrophiles (Hwang et al., 2003). Oedema induced by carrageenan after $2^{\text {rd }}$ hour of injection indicates the second phase of applying acute inflammatory model which is mediated by prostaglandins, the cycloxygenase products and lipoxygenase products (Vinegar et al., 1969). Non-steroidal anti-inflammatory agents inhibit cyclooxygenase (COX-2) enzymes involved in prostaglandin synthesis (Dosseh et al., 2014). Based on these reports it is possible that the inhibitory effect of the plants organs extract on carrageenan-induced inflammation in rats could be due to inhibition of cyclooxygenase leading to inhibition of prostaglandin synthesis. Although the cyclooxygenase and lipoxygenase pathways are both involved in the inflammatory process inhibitors of cyclooxygenase are more effective in inhibiting carrageenan-induced inflammation than lipoxygenase inhibitors (Shaheen et al., 2013). In our experiment, rats pre-treated with P. dulce stem bark, S. longepedunculata root bark and C. sanguinolenta root bark hydroethanolic extract showed a significant oedema inhibitory response after first, third and fifth hour following carrageenan injection. In the results of second hour, the most suitable inhibition of oedema was found with $S$. longepedunculata extract. This result suggests that all the three plant extract may act by suppressing the later phase of the inflammatory process by the inhibition of cyclooxygenase. So, inhibition of carrageenan induced paw oedema by hydroethanolic extract could be due to its inhibitory activity on the prostaglandins (Shaheen et al., 2013). From the three plant extracts S. longepedunculata demonstrated the highest inhibition percentage. The antinflammatory activity of the plant was previously described by Ojewole (2008), but the test was conducted on streptozoncin diabetic rats. Muanda et al., 2010 observed that S. longepedunculata extract had good anti-inflammatory properties in the in vitro nitrite assay by inhibiting NO production in activated macrophages. As Cryptolepine is the major alkaloid of the West African shrub, Cryptolepis sanguinolenta, it has been shown to inhibit nitric oxide production too.

For many in vitro studies LOXs has been postulated to play an important role in the pathophysiology of several inflammatory and allergic diseases (Sacan and Turhan 2014). Lipoxygenases are lipid-peroxidizing enzymes involved in the biosynthesis of leukotriene from arachidonic acid, mediators of inflammatory and allergic reactions. These enzymes catalyze the addition of molecular oxygen to unsaturated fatty acids such as linoleic and arachidonic acids (Porta et al., 2002 Adebayo et al., 2015). There are four main iso-enzymes already described, namely, 5-LOX, 8LOX, 12-LOX and 15-LOX, depending on the site of oxidation in the unsaturated fatty acids (Porta and Rocha-Sosa, 2002). The common substrates for LOX are linoleic and arachidonic acids. Reactive oxygen radicals (ROS) are well known to be produced during the inflammatory process (Trouillas et al., 2003). In this study, the three plant extracts showed strong LOX inhibitory activity which was best with $C$. sanguinolenta extract with $\mathrm{IC}_{50}=0.47 \pm 0.03 \mu \mathrm{g} / \mathrm{ml}$. Werz (2007) stated that a plant extract power inhibition of LOX depends on its quantity of polyphenols. 
Other researchers as Yoon and Baek (2005) have shown the role of antioxidants in the inhibition of inflammatory enzymes such as LOX enzymes (Yoon and Baek, 2005). These assessments were in disagreement with our findings; hence $P$. dulce possessed the highest quantity of polyphenolic compounds but wasnot the strongest in inhibiting LOX; another molecules or process must be involved in this mechanism. The anti-inflammatory reference product Zileuton had IC50 of $0.083 \mu \mathrm{g} / \mathrm{ml}$, about 9.39 times higher than $P$. dulce and S. longepedunculata, and 5.66 times that of $C$. sanguinolenta. Many other plant extracts and chemical compounds have been tested for LOX inhibition according to Sacan and Turhan (2014) and demonstrated good $\mathrm{IC}_{50}$. Plant extracts, except garlicand grape extracts have inhibited LOX at a higher rate than quercetin. Celik Onar et al., (2012) have demonstrated that Epilobium angustofolium extract inhibited the activity of lipoxygenase; $\mathrm{IC}_{50}$ value was found as $0.57 \pm 0.06 \mu \mathrm{g} / \mathrm{ml}$. Higher value of LOX activity $\mathrm{IC}_{50}=62.6 \mu \mathrm{g} / \mathrm{ml}$ with the bark of $F$. rhynchophylla has been found according to Huh et al. (2015). Therefore, the selective inhibition of LOX is an important therapeutic strategy for asthma (Shah et al., 2011; Schneider and Bucar. 2005). Medicinal plants may therefore be potential sources of inhibitors of COX-2/LOX that may have fewer side effects than NSAIDs (Schneider and Bucar, 2005). Inhibitors of LOX activities could provide potential therapies to manage many inflammatory and allergic responses and serve as ZYFLO $600 \mathrm{mg} \mathrm{cp}$ pellic made up with Zileuton.

Protein electrophoresis has been a proven diagnostic technique to examine proteins in plasma or serum in human (Ngure et al., 2008; Crivellente et al., 2008). The study carried out with the electrophoretic profiles has shown that the serum proteins concentrations of wistar rats were different, whether they received or not plants extracts. Through osmotic pressure, serum protein is involved in the maintenance of normal distribution of water between blood and tissues (Marchi et al., 2009). Several fractions of serum vary independently and widely in diseases (Crivellente $e t$ al., 2008). The main idea was to assess the impact of these extracts on possible changes induced on these proteins six hours after the inflammation induction by the carrageenan. This molecule is a mixture of sulphated polysaccharides extracted from red algae, gelling and immunogenic equivalent to lipopolysaccharide (LPS) (Tobacman, 2001) of the outer membrane of Gram-negative bacteria including Klebsiella pneumoniae (Podschun, and Ullmann, 1998). It disrupted the total protein level by decreasing the concentration in negative control group but indomethacin, the reference anti-inflammatory drug has slightly corrected the diminution significantly. All extracts have acted in the same way but statistically unproved. Generally the inflammatory state is marked by the increase of alpha1, alpha2-globulin and the decrease of gamma-globulins. The gamma globulins produced by differentiated lymphocytes, the plasmocyte contain the IgG, IgM, IgA, IgE, and IgD immunoglobulins (Zaias et al., 2009). These are antibodies produced by the organism during intrusion of foreign agent. No change was observed with gamma globulin due probably to the short period of inflammation installation. Plant extracts such as $P$. dulce at $0.4 \mathrm{~g} / \mathrm{kg}$ and $C$. sanguinolenta at $0.8 \mathrm{~g} / \mathrm{kg}$ were more suitable for immunomodulating than indomethacin because they have suppressed the effect induced by carrageenan on immunoglobulins. The potentiating of the immunosuppressive effects created was observed with the extract of $P$. dulce and $S$. longepedunculata at $0.8 \mathrm{~g} / \mathrm{kg}$ and at a dose of $0.4 \mathrm{~g} / \mathrm{kg}$ for the extracts of C. sanguinolenta and $S$. longepedunculata.

During inflammation process, generally the number of WBC is increased at a short period of time (Porth, 2011). This was effective because animal group treated with carrageenan had a high number of leucocytes $(13.58 \pm$ $1.1110^{3}$ cells $\left./ \mathrm{mm}^{3}\right)$ if compared to group without carrageenan $\left(8.72 \pm 1.22 .10^{3}\right.$ cells $\left./ \mathrm{mm}^{3}\right)$. The corrective action we were looking for from plant extracts was only found with C. Sanguinolenta at dose $0.8 \mathrm{~g} / \mathrm{kg}\left(11.60 \pm 1.4910^{3}\right.$ cells $/ \mathrm{mm}^{3}$ ) and with $S$. longepedunculata at doses of 0.4 and $0.8 \mathrm{~g} / \mathrm{kg}$ with approximately the same value. The number of platelets was also very influenced by carrageenan during our experiment. Only $P$. dulce extract at $0.8 \mathrm{~g} / \mathrm{kg} \mathrm{protected}$ platelets from lowering effect induced by inflammation caused by carrageenan injection. Negative effect was observed mainly with the $S$. longepedunculata extract; the mechanism is not understood. Inflammation can also affect number of red blood cells and haemoglobin meaning inflammatory anemia (Berger, 2007; Lee et al., 2014). That effect was not been observed in our study probably due to the impact delay on those parameters. Further investigations on this way must be performed to better understand the mechanisms.

Conflict of interest: The authors declare no conflict of interest

Acknowledgements: the authors thank the staff of the Polyclinelle Wossinu-Gbogbo of Lomé for the kind collaboration.

\section{References}

1. Adebayor, S.A., Dzoyem, J.P., Shai, L.J., Eloff, J.N. (2015). The anti-inflammatory and antioxidant activity of 25 plant species used traditionally to treat pain in southern African. BMC Complementary and Alternative Medicine 15, 159.

2. Adwan, G., Abu-Shanab, B., Adwan, K. (2010). Antibacterial activities of some plant extracts alone and in combination with different antimicrobials against multidrug-resistant Pseudomonas aeruginosa strains. Asian Pacific Journal of Tropical Medecine 3(4), 266-9.

3. Akinmoladun, A.C., Obuotor, E.M., Farombi, E.O. (2010). Evaluation of Antioxidant and Free Radical Scavenging Capacities of Some Nigerian Indigenous Medicinal Plants. Journal of Medicinal Food 13 (2), 444-451.

4. Alfadda, A.A., Sallam, R.M. (2012). Reactive Oxygen Species in Health and Disease. Journal of Biomedicine and Biotechnology, Volume 2012, Article ID 936486, 14 p. 
5. Azila, Y., Don, M.M. (2012). Evaluation of Trametes lactinea extracts on the inhibition of hyaluronidase, lipoxygenase and xanthine oxidase. Journal of Physical Science 23, 1-15.

6. Baker, H.J., Lindsey, J.R., Weisbroth, S.H. (1979). Housing to control research variables. In: The Laboratory Rat, Vol. I. Biology and Diseases (H.J. Baker, R.J. Lindsey, S.H. Weisbroth, eds.). Academic Press, New York, NY. Pp. 169192.

7. Barbosa, T.M., Levy, S.B. (2000). The impact of antibiotic use on resistance development and persistence. Drug Resistance Updates 3, 303-311.

8. Barku, V.Y.A., Opoku-Boahen, Y., Dzotsi, E. Y. (2012). Isolation and pharmacological activities of alkaloids from Cryptolepis sanguinolenta (Lindl) schlt. International Research Journal of Biochemistry and Bioinformatics 2(3), 5861.

9. Berger, J. (2007). Phenylhydrazine haematotoxicity. Journalof Applied Biomedecine 5, 125-130.

10. Betoni, J.E.; Mantovani, R.P.; Barbosa, L.N.; di Stasi, L.C.; Junior, A.F. (2006). Synergism between plant extract and antimicrobial drugs used on Staphylococcus aureus diseases. Memorias Do Instituto Oswaldo Cruz 101, 387-390.

11. Boye, LG., Oku-Ampofo, O. (1990). Medicinal plants in Ghana. Economic and Medicinal Plant research. Plants Traditional Medecine 4, 32-33.

12. Bradley, J.S., Arrieta, A. (2001). Empiric use of cefepime in the treatment of lower respiratory tract infections in children. Pediatric Infectious Diseases Journal 20, 343-9.

13. Brooker, R.J. (2011). Genetics: analysis and principles (4th ed.). McGraw-Hill Science. ISBN 978-0-07-352528-0.

14. Bugyei, K.A., Boye, G.L., Addy, M.E. (2010). Clinical Efficacy of a Tea-Bag Formulation of Cryptolepis Sanguinolenta Root in the Treatment of Acute Uncomplicated Falciparum Malaria. Ghana Medicinal Journal 44(1), 3 9.

15. Celik O.H., Yusufoglu, A., Turker, G., Yanardag, R. (2012). Elastase, tyrosinase and lipoxygenase inhibition and antioxidant activity an aqueous extract from Epilobium angustifolium L. leaves. Journal of Medicinal Plant Research 6, 716-726.

16. Chamorro, S., Goni, I., Viveros, A., Hervert-Hernandez, D., Brenes A. (2012). Changes in polyphenolic content and antioxidant activity after thermal treatments of grape seed extract and grape pomace. European Food Research and Technology 234, $147-155$.

17. Chedea, V.S., Jisaka, M. (2013). Lipoxygenase and carotenoids: A co-oxidation story. African Journal of Biotechnology 12(20), 2786-2791.

18. Chen, C.H., Chan, H.C., Chu, Y.T., Ho, H.Y., Chen, P.Y., Lee, T.H., Lee, C.K. (2009). Antioxidant activity of some plant extracts towards xanthine oxidase, lipoxygenase and tyrosinase. Molecules 14, 2947-2958.

19. Compaore, M., Lamien-Meda, A., Mogoşan, C., Lamien, C.E., Kiendrebeogo, M., Voştinaru, O., Vlase, L., Ionescu, C., Nacoulma, O.G. (2011). Antioxidant, diuretic activities and polyphenol content of Stereospermum kunthianum Cham. (Bignoniaceae). Natural Product 25(19), 1777-88.

20. Crivellente, F., Bonato, M., Cristofori, P. (2008). Analysis of mouse, rat, dog, marmoset, and human serum proteins by capillary electrophoresis: comparison with agarose gel electrophoresis. Veterinary Clinical Pathology 37, 73-78.

21. Davies, J., Davies, D. (2010). Origins and Evolution of Antibiotic Resistance. Microbiology and Molecular Biology Reviews 74(3), 417-433.

22. Delgado-Valverde, M., Sojo-Dorado, J., Pascual, A., Rodriguez-Bano, J. (2013). Clinical management of infections caused by multidrug-resistant Enterobacteriaceae. Therapeutic Advances in Infectious Disease 1(2), 49-69.

23. Demain, A.L., Sanchez, S. (2009). Microbial drug discovery: 80 years of progress. The Journal of Antibiotics 62, 5-16.

24. Dosseh, K., Kpatcha, T., Adjrah, Y., Idoh, K., Agbonon, A., Gbéassor, M. (2014). Anti-inflammatory effect of Byrsocarpus coccineus Schum. And thonn. (connaraceae) root World Journal of Pharmaceutical Research 3 (3), 3585 3598

25. Fankam, A.G., Kuete, V., Voukeng, I.K., Kuiate, J.R., Pages, J.M. (2011). Antibacterial activities of selected Cameroonian spices and their synergistic effects with antibiotics against multidrug-resistant phenotypes. BMC Complementary and Alternative Medecine, 11:104.

26. Halliwell, B., Gutteridge, J.M. (1998). Free radicals in biology and medicine Oxford: Oxford University Press. 944 pages

27. Huh, M., K., Cho, K-S., Jeon, S-J. (2015). Inhibitory effect of lipoxygenase and DPPH radical scavening activity of Fraxinus rhynchophylla. European Journal of Advanced Research in Biological and Life Sciences 3 (3), $2056-5984$.

28. Hwang, T-L., Hung, H-W., Kao, S-H., Teng, C-M., Wu, C-C., Cheng, S.J-S. (2003). Soluble guanylyl cyclase activator YC-1 inhibits human neutrophil functions through a cGMP-independent but cAMP-dependent pathway. Mol Pharmacol 64, 1419-1427.

29. Illiaquer, M. (2010). Epidémiologie et caractérisation moléculaire des souches cliniques de Klebsiella pneumoniae résistantes aux céphalosporines de troisième génération hors BLSE isolées entre 2007 et 2009 au CHU de Nantes. Thèse de doctorat; Thèse pour le Diplôme d'Etat de Docteur en pharmacie. $\mathrm{N}^{\circ} 41$.

30. Ishaq, M., S., Razaq, A., Hussain, M., M., Ali, G., Khattak, M., Amin, M. (2015). In vitro interaction of antimicrobial agents in combination with plant extract against multidrug-resistant bacterial strains. Malaysian Journal of Microbiology 11(3), 300-305.

31. Kamatou, G.P.P.; Viljoen, A.M.; Van Vuuren, S.F.; Van Zyl, R.L. (2006). In vitro evidence of antimicrobial synergy between Salvia chamelaeagnea and Leonotis leonurus. South African Journal of Botany 72, 634-636. 
32. Karou, S.D., Tchacondo, T., Tchibozo, M.A., Anani, K., Ouattara, L., Simpore, J., de Souza, C. (2012). Screening Togolese medicinal plants for few pharmacological properties.Pharmacognosy Research 4, 116-22.

33. Katekhaye, S.D., Kale, M.S. (2012). Antioxidant and free radical scavenging activity of Pithecellobium dulce (Roxb.) Benth wood bark and leavesFree Radicals andAntioxidants 2(3), 47-57.

34. Kumar, R.; Clermont, G.; Vodovotz, Y.; Chow, C.C. (2004). The dynamics of acute inflammation. Journal of Theoretical Biology 230 (2), 145-155.

35. Kumar, T., Jain V. (2014). Antinociceptive and Anti-Inflammatory Activities of Bridelia retusa Methanolic Fruit Extract in Experimental Animals, The Scientific World Journal 2014, 12 pages.

36. Kye, I.S. Huh, M.K. (2015). Inhibitory effect of Lipoxygenase and DPPH Radical Scavenig Activity of Perilla Frutescens Var. Acuta. European Journal of Advanced Research in Biological and Life Sciences 3, 24-30.

37. Lee, H.W., Kim, H., Ryuk, J.A., Kil, K-J., Ko, B.S. (2014). Hemopoietic effect of extracts from constituent herbal medicines of Samul-tang on phenylhydrazine induced hemolytic anemia in rats. Intetnational Journal of Clinical and Experimental Pathology 7(9), 6179-6185.

38. Majumdar, M., Simes, D.C., Prabha, R.D. (2009). Cerebritis: An unusual complication of Klebsiella pneumoniae. Indian Journal of Critical Care Medicine 13(1), 37-40.

39. Marchi, N., Betto, G., Fazio, V., Fan, Q., Ghosh, C., Machado, A., Janigro D. (2009). Blood-brain barrier damage and brain penetration of antiepileptic drugs: Role of serum proteins and brain edema. Epilepsia 50(4), 664-677.

40. McDonald, M., Currie, B.J., Carapetis, J.R. (2004). Acute rheumatic fever: a chink in the chain that links the heart to the throat? Lancet Infectious Diseases 4 (4), 240-245

41. Meriles, J.M., Guzmán, C.A., Maestri, D.M. (2000). Lipoxygenase-1 Activity of Soybean Genotypes Grown in Argentina. Molecules 5, 475-478.

42. Mills-Robertson, F.C., Tay, S.C.K., Duker-Eshun, G., Walana, W., Badu, K. (2012). In vitro antimicrobial activity of ethanolic fractions of Cryptolepis sanguinolenta. Annals of Clinical Microbiology and Antimicrobials, 11:16.

43. Muanda, F.N., Dicko, A., Soulimani, R. (2010). Assessment of polyphenolic compounds, in vitro antioxidant and antiinflammation properties of Securidaca longepedunculata root barks. Comptes Rendus Biologies 333, 663-669.

44. N'guessan, J.D., Dinzedi, M.R., Guessennd, N., Coulibaly, A., Dosso, M., Djaman, A.J., Guede-Guina, F. (2007). Antibacterial activity of the aqueous extract of Thonningia sanguinea against Extended-Spectrum- $\beta$-Lactamases (ESBL) producing Escherichia coli and Klebsiella pneumoniae strains. Tropical Journal of Pharmaceutical Research 6 (3), 779-783.

45. National Committee for Clinical Laboratory Standards. (2002). Performance standards for antimicrobial susceptibility testing. Twelfth informational supplement M100-S12. National Committee for Clinical Laboratory Standards, Wayne, Pa.

46. Ndamitso, M.M., Mohammed, A., Jimoh, T.O., Idris, S., Oyeleke, S.B., Etsuyankpa, M.B. (2013). Phytochemical and antibacterial activity of Securidaca longepedunculata on selected pathogens. African. Journal.of Microbiology. Research 7(50), 5652-5656.

47. Ngure, R.M., Eckersall, P.D., Jennings, F.W., Mburu, J., Burke, J., Mungatana, N., Murray, M. (2008). Acute phase response in mice experimentally infected with Trypanosoma congolense: a molecular gauge of parasite host interaction. Veterinary Parasitology 151, 14-20.

48. Ojewole, JA (2008).Analgesic, anti-inflammatory and hypoglycaemic effects of Securidaca longepedunculata (Fresen.) [Polygalaceae] root-bark aqueous extract. Inflammopharmacology 16(4):174-81.

49. Olajide, O.A., Awe, S.O., Makinde, J.M., Ekhelar, A.I., Olusola, A., Morebise, O., Okpako, D.T. (2000). "Studies on the anti-inflammatory, antipyretic and analgesic properties of Alstonia boonei stem bark," Journal of Ethnopharmacology 71(1-2), 179-186.

50. Olajuyigbe, O.O., Afolayan, A.J. (2012). Synergistic Interactions of Methanolic Extract of Acacia mearnsii De Wild. with Antibiotics against Bacteria of Clinical Relevance. International Journal of Molecular Sciences Impact \& Description 13, 8915-8932.

51. Perjesi, P., Rozmer, Z. (2011). Kinetic analysis of some chalcones and synthetic chalcone analogues on the fentonreaction initiated deoxyribose degradation assay. Medicinal Chemistry Journal 5, 61-7.

52. Podschun, R; Ullmann, U. (1998). "Klebsiella spp. as Nosocomial Pathogens: Epidemiology, Taxonomy, Typing Methods, and Pathogenicity Factors". Clinical Microbiology Reviews 11 (4), 589-603.

53. Porta, H., Rocha-Sosa, M. (2002). Plant lipoxygenases, physiological and molecular features. Plant Physiology 130, 15-21.

54. Porth, Carol Mattson (2011), "White blood cell response", Essentials of Pathophysiology: Concepts of Altered Health States (3rd ed.), Philadelphia: Wolters Klower Health/Lippincott Williams \& Wilkins, pp. 64-65,

55. Pradeepa, S., Subramanian, S., Kaviyarasan, V. (2014). Evaluation of antimicrobial activity of Pithecellobium dulce pod pulp extract; Asian Journal of Pharmaceutical and Clinical Research 7(1), 32-37.

56. Rani, S., Lakshmi, M.T., Sankeerthi, V.L.S., Kiran, R.S.B., Bagyalakishmi, R., Reddy, P.E. (2013). Distribution of Staphylococcus aureus and Pseudomonas aeruginosa in chronicwounds. Journal of Current Trends in Clinical Medicine and Laboratory Chemistry 2(2), 15-19.

57. Reuter, S., Gupta, S.C., Chaturvedi, M.M., Aggarwal, B.B. (2010). Oxidative stress, inflammation, and cancer: How are they linked? Free Radical Biology \& Medicine, 49(11), 1603-1616.

58. Sacan, O., Turhan, E.Y. (2014). Lipoxygenase Inhibitory Activities of Some Plant Extracts and Chemical Compounds IUFS Journal of Biology 73(2), 47-52. 
59. Schneider, I., Bucar, F. (2005). Lipoxygenase inhibitors from natural plant sources. Part 1: Medicinal plants with inhibitory activity on arachidonate 5-lipoxygenase and 5-lipoxygenase/cycloxygenase. Phytotherapy Research 19, 81102.

60. Serhan C.N, Savill J and Savill. (2005)."Resolution of inflammation: the beginning programs the end". Nat. Immunol. 6(12), 1191-1197.

61. Shah, B.N., Seth, A.K., Maheshwari, K.M. (2011). A review on medicinal plants as a source of anti-inflammatory agent. Res J Med Plant. 5(2):101-15.

62. Shaheen N., Ahmed S., Azhar I., Hasan, M. M. (2013). Analgesic, anti-inflammatory and antiemetic activities of Cleome scaposa DC. Phytopharmacology 4(1), 106-113

63. Shaikh, S., Fatima, J., Shakil, S., Rizvi, S.M.D., Kama, M.A. (2015). Antibiotic resistance and extended spectrum betalactamases: Types, epidemiology and treatment. Saudi Journal of Biological Sciences 22, 90-101.

64. Spooner, R., Yilmaz, Ö. (2011). The Role of Reactive-Oxygen-Species in Microbial Persistence and Inflammation. International Journal Molecular Sciences 12, 334-352.

65. Stermitz, F., Lorenz, P., Taawara, J.N., Zenewicz, L.A. and Lewis, K. (2000). Synergism in a medicinal plant: Antimicrobial action of berberine potentiated by S-methoxyhydrocarpin-a multidrug pump inhibitor. Proceedings of National Academy of Sciences 97(4), 1433-1437.

66. Tobacman JK (2001) Review of Harmful Gastrointestinal Effects of Carrageenan in Animal Experiments. Environmental Health Perspectives 109(10): 983-994

67. Trouillas, P., Calliste, C.A., Allais, D.P., Simon, A., Marfak, A., Delage, C., Duroux, J. L. (2003). Antioxidant, antiinflammatory and antiproliferative properties of sixteen water extracts used in the Limousin countryside as herbal teas. Food Chemistry 80, 399-407.

68. Velazquez, E., Tournier, H.A., de Buschiazzo, P.M., Saavedra, G., Schinella, G.R. (2003). Antioxidant activity of Paraguayan plant extracts. Fitoterapia 7, 91-97.

69. Vinegar, R., Schriber, W., Hugo, R. (1969). Biphasic development of carrageenan edema in rats. Journal of Pharmacology and Experimental Therapeutics 166, 96-103.

70. Werz, O. (2007). Inhibition of 5-lipoxygenase product synthesis by natural compounds of plant origin. Planta Medica $73,1331-1357$.

71. Winter, C.A., Risley, E.A., Nuss, C.W. (1962). Carrageenin-induced edema in hind paw of the rat as an assay for antiiflammatory drugs. Proceedings of the Society for Experimental Biology and Medicine 111, 544-547.

72. Wisastra, R., Dekker, F.J. (2014). Inflammation, Cancer and Oxidative Lipoxygenase Activity are Intimately Linked. Cancers 6, 1500-1521.

73. Woldu, M.A. (2016). Klebsiella pneumoniae and Its Growing Concern in Healthcare Settings. Clinical and Experimental Pharmacology 6, 199 doi: 10.4172/2161-1459.1000199

74. World Health Organization. (2014) World malaria report 2014. Geneva: World Health Organization. http://www.who.int/malaria/publications/world_malaria_report_2014/wmr-2014-no-profiles.pdf [Accessed on 20th December, 2015]

75. Yazdanparast, R., Bahramikias, S., Ardestani, A. (2008). Nasturtium oficinale reduces oxidative stress and enhances antioxidant capacity in hypercholesterolaemic rats. Chemico-Biological Interactions Journal 172, $176-84$.

76. Yoon, J-H., Baek S.J. (2005). Molecular Targets of Dietary Polyphenols with Anti-inflammatory Properties Yonsei Medical Journal 46 (5), 585 - 596.

77. Zaias, J., Mineau, M., Cray, C., Yoon, D., Altman, N.H. (2009). Reference Values for Serum Proteins of Common Laboratory Rodent Strains. Journal of the American Association for Laboratory Animal Science 48 (4), $387-390$. 